UDC 519.766.2

Andrei Shumkov

Saint Petersburg State Electrotechnical University

\title{
FORMAL MODELING CONSIDERATIONS \\ FOR DEPENDENT CLAUSE WITH VACANT SUBJECT IN SOME GERMANIC LANGUAGES
}

For citation: Shumkov A. A. Formal modeling considerations for dependent clause with vacant subject in some Germanic languages. Scandinavian Philology, 2018, vol. 16, issue 2, pp. 293-307. https://doi.org/10.21638/11701/spbu21.2018.207

Dependent clauses with vacant subject are considered in contraposition to independent clauses with vacant subject, which refer to interrogative sentences with unknown subject being sought by means of compulsory interrogative element. The languages particularly involved are English, Dutch and Swedish. Within the binomiality idea a formal modeling is undertaken to explain the syntactic nature of the formal particle in a subject. Main and secondary substantive / verbal sentence parts are assumed to consist of two parts - a space / time specifier or proto-specifier and a substantive / verbal semifinitive. The formal particle in a subject is associated with a strong or super-strong space specifier. In an independent and dependent interrogative sentence, as well as in a dependent narrative one, the fixing of a principal substantive semifinitive is postulated to start with a super-strong specifier. It is proposed that in independent / dependent clauses the use of the formal particle is stipulated by a possible opposition of a fixing verbal semifinitive against the pressure of outer space, as well as by informativity of an interrogative / conjunctive element. For dependent clauses it is also established that the formal particle in Danish and, sometimes in English, can fill (or accompany) the vacant strong substantive semifinitive and terminate its being vacant; Swedish and Norwegian use for this, instead of the formal particle, an adverbial-substantive unit. Filling the vacant strong substantive semifinitive makes the main sentence parts complete, and a dependent clause becomes more similar to an independent clause. It confirms the statement of the binomiality idea that a narrative and interrogative dependent clause is syntactically «in-between» a narrative independent clause and an interrogative independent clause. Still, the use of the vacant or non-vacant strong substantive semifinitive can be stipulated, like in Danish, by the informativity of the conjunctive ele- 
ment. In case of a high informativity of the conjunctive element the strong substantive semifinitive may remain vacant.

Keywords: linguistic modeling, syntax of Germanic languages, dependent clauses, null-subject, binomiality idea, semifinitive.

Dependent clauses with vacant subject reveal evident similarity to independent clauses with vacant subject. The latter ones refer to the case of interrogative sentences, where subject is not known and being sought for by means of compulsory interrogative element, which can be word or word combination. An example for this case can be Who is asked? or Which books lie on the table?, because subject in these sentences is not yet found. In the second sentence, of course, it is known, that we are seeking for books, but still it cannot be established for sure, which books they will be. Transformation of these sentences into dependent clauses will result, respectively, in I know, who is asked and I know, which books lie on the table.

Rather artificial constructions, but, nevertheless, grammatically allowable, may also occur in independent clauses - Who is there asked?, Which books do there lie on the table? and, with two variations, in dependent clauses - I know, who there is asked, I know, which books there lie on the table or I know, who is there asked, I know, which books lie there on the table.

In other Germanic languages, more or less relevant to English, we see similar situation. The considered English sentences can be translated in a structural correspondence.

In Dutch, which is more related to English, there may exist constructions like Wie wordt gevraagd?, Welke boeken liggen op de tafel? and Ik weet, wie gevraagd wordt (or Ik weet, wie wordt gevraagd), Ik weet, welke boeken op de tafel liggen.

Dutch grammar also allows constructions, which, in comparison with corresponding English clauses, look less artificially. So, in independent clauses there occur constructions Wie wordt er gevraagd?, Welke boeken liggen er op de tafel? and, in dependent clauses - Ik weet, wie er gevraagd wordt (or Ik weet, wie er wordt gevraagd), Ik weet, welke boeken er op de tafel liggen.

In Swedish, which is less related to English, there may exist constructions like Vem är frågad (or Vem frågas?), Vilka böcker ligger på bordet? and Jag vet vem som är frågad (or Jag vet vem som frågas), Jag vet vilka böcker som ligger på bordet. 
Swedish grammar also allows constructions, which, in comparison with corresponding English and Dutch dependent clauses, look more artificially - Jag vet vem där/det är frågad (or Jag vet vem där/det frågas), Jag vet vilka böcker där/det ligger på bordet. Independent clauses like Vem är där/det frågad (or Vem frågas där/det?), Vilka böcker ligger där/det på bordet? are the most artificial and occur rather seldom.

The provision of vacant subject with a formal particle, which has no lexical meaning, causes many questions of grammatical and semantic nature [Finch, 2000, p. 97]. In the most abstract models the absence of lexical meaning is not taken as a serious lack - originally the consideration of language starts with syntactic structures and then comes to mental ones [Chomsky, 2006]. Only cognitive grammar tries to find a common base for language and meaning, but the ways it uses are far from approaches, usual in natural sciences [Jacckendoff, 2003]. Up till now there is no radical explanation, why words exist, and are organized, and sometimes lose, after having been organized, their lexical meanings. We will try to explain it in a very new way [Shumkov, 2017].

In 1993 at Saint-Petersburg Electrotechnical University the so-called binomiality idea was stated, according to which any verbal or substantive part of the sentence comprises, explicitly or implicitly, two pieces - specifier (proto-specifier) and semifinitive. For the first time in syntax there was proclaimed, that the main parts of sentence are formed dependently on the type of the sentence.

Subject / predicate is formed by fixing a verbal / substantive semifinitive in a time / space specifier. Secondary verbal / substantive part is formed by fixing a verbal / substantive semifinitive in a time / space proto-specifier. The difference between specifiers and proto-specifiers is as follows: proto-specifiers may only have diffused (weak) shape; specifiers may have diffused (weak), concentrated (strong) and over-concentrated (super-strong) shape.

Weak proto-specifier or weak specifier is a flexion (sometimes a null-flexion); strong or super-strong specifier is a word, mostly desemantizated. The three shapes of a specifier are explained by a semifinitive also having three shapes - super-weak, weak and strong ones, what, optimally, leads to the following balance when fixing a semifinitive in a specifier: strong semifinitive in weak specifier, weak semifinitive in strong specifier, super-weak semifinitive in super-strong specifier. Nevertheless, weak and super-weak semifinitive may also be fixed 
in weak specifier / proto-specifier. Semifinitives contain inner time or space; specifiers and proto-specifiers - outer one.

A semifinitive consists of a membrane and a cavity inside it. In substantive semifinitive uninflected and inflected words are always distributed into the membrane. In verbal semifinitive uninflected word is always distributed into the membrane, and inflected word(s) (participle(s) or other extensions) - into the cavity. A vacant semifinitive is a semifinitive with empty membrane and cavity, when no word is distributed into them. A specifier / proto-specifier consists of a cavity outside it [Szumkov, 2014].

Because of the common concept of semifinitive the categories of verbal aspect and substantive determination are considered within the binomiality idea as united. Different sizes of the semifinitive cavities are stipulating verbal aspects and substantive determinations. If the cavity of verbal or substantive semifinitive is large, the verbal unit is imperfect and substantive unit is definite. If the cavity of verbal or substantive semifinitive is small, the verbal unit is perfect and substantive unit is indefinite [Szumkov, 2014].

It should be noted, that the binomiality idea becomes considerably complicated in the assumption, that the fixation of semifinitive in specifier may turn into a modification of specifier by semifinitive. The difference between fixation and modification is as follows: fixation arithmetically corresponds to multiplication, and modification - to addition. Thus, in the result of fixation we get a three-dimensional image, which is a main or secondary part of sentence, and in the result of modification - still one-dimensional image, which is a modified specifier [Choumkov, 2013]. The implementation of the modification allows explaining some specific syntactical phenomena.

It should also be noted, that a weak specifier, modified by a strong semifinitive, becomes transformed from flexion into word and gets from the semifinitive, mostly, a modal semantics. A weak specifier, modified by a super-weak semifinitive, becomes transformed from flexion into ending, which also has a chance to be modified by a strong semifinitive and become transformed into word with a modal semantics.

As it was said above, the binomiality idea proclaims, that the main parts of sentence are formed according to the type of the sentence. Let us consider the independent clause. In narrative affirmative sentences the specifiers of the verbal and substantive semifinitives are firstly weak, 
secondly — strong, and thirdly - super-strong. In narrative negative sentences the specifier of the verbal semifinitive is firstly super-strong, secondly - strong and thirdly - weak, and the specifier of the substantive semifinitive is firstly weak, secondly — strong, and thirdly - super-strong. In interrogative affirmative and negative sentences the specifiers of the verbal and substantive semifinitives are firstly super-strong, secondly — strong and thirdly - weak. The freedom of these three steps allows us to support weak and super-weak semifinitives and to express the grammatical meanings of modality and emphasis. In addition it explains (and not only for English), why it is not possible to compose interrogative affirmative sentences like Is to read books useful? and why it is nevertheless possible to compose narrative affirmative sentences like To read books is useful. It also explains why interrogative affirmative sentences are like Does he read books? and why narrative affirmative sentences are like He reads books. As well, we have a very nice explanation of why the constructions with there mostly require indefinite noun, like in There is a girl in the room and never may be built on pronoun semifinitive - it is impossible to have a sentence like There is he in the room. Let us consider the dependent clause. In narrative and interrogative affirmative sentences the specifier of the substantive semifinitive is firstly super-strong, secondly - strong and thirdly - weak, and the specifier of the verbal semifinitive is firstly weak, secondly - strong, and thirdly - super-strong. In narrative and interrogative negative sentences the specifiers of the verbal and substantive semifinitives are firstly super-strong, secondly — strong and thirdly — weak.

Predicate and subject reveal time and space elements. In the case of super-strong and strong specifiers time and space elements coincide with them. If the case of weak specifiers these are inflected semifinitive membranes, which become time and space elements. For example, in the sentence Does he read books? the time element is does and the space

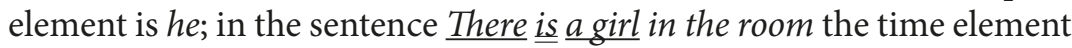
is $i$ and the space element is there. It can be easily seen, that time element can coincide with predicate and space element can coincide with subject. For example, in the sentence He reads books the time element is reads; in the sentence $A$ girl is in the room the space element is a girl.

Time and space elements are arranged depending on the sentence type as well. For independent clause in narrative affirmative and negative sentences the space element precedes the time element; in inter- 
rogative affirmative and negative sentences the time element precedes the space element. For dependent clause in narrative and interrogative affirmative and negative sentences the space element precedes the time element.

If we look attentively at the construction of the specifiers, we discover, that the time specifiers may exist either in the present or in the past, and there is no tense, when present and past are together. The space specifiers exist both in the up-side and in the down-side, and in fact there is no difference in sides at all (otherwise we should have a grammatical dependence on, let us say, left- or right-side, what is not observed in the language). So, the time specifier is divided into two planes and the space specifier not. It metaphysically means that the pressure of a time specifier is two times less, than the pressure of a space specifier [Ulianitckaia, Shumkov, 2018].

We have marked, that the pressure of specifiers influences the semifinitives. The influence of time pressure on substantive semifinitives is negligible, whereas the influence of space pressure on verbal semifinitive is significant. Under increasing the space pressure the relief of the verbal semifinitive membrane becomes more flat, and the lexical meaning dims. In case the subject is built on the weak space specifier the use of all possible verbal semifinitives is allowed. In case the subject is built on the strong space specifier one may use less verbal semifinitives, semantically resembling with the semifinitives be and have been. In case the subject is built on the super-strong space specifier it it is only possible to use the semifinitives be $a$ and have been $a$, where $a$ is adjective (be useful and have been useful) or adjective unit (be of use and have been of use).

Let us consider the sets of English, Dutch and Swedish specifiers in details.

In English there are the following specifiers - for time: super-strong (no modification is allowed), strong (no modification is allowed), weak (strong modification is allowed); for space: super-strong (no modification is allowed), strong (no modification is allowed), weak (super-weak modification is allowed).

In Dutch there are the following specifiers - for time: super-strong (super-weak modification is allowed), weak (strong modification is allowed); for space: super-strong (no modification is allowed), strong (no modification is allowed), weak (super-weak modification is allowed). 
In Swedish there are the following specifiers - for time: super-strong (super-weak modification is allowed), weak (strong modification is allowed); for space: super-strong (no modification is allowed), strong (no modification is allowed), weak (super-weak modification is allowed).

So, the main parts of the sentence in English, Dutch and Swedish are formed according to a general scheme, but, even in case of unmodified specifiers, reveal a difference. In case of modified specifiers this difference is bigger.

Let us limit ourselves by affirmative sentences with vacant subject both in independent and dependent clauses.

In independent clause we deal with interrogative sentences. When forming predicate we move from super-strong time specifier to weak one and do not take into account their pressure on the fixing substantive semifinitive. The only thing we should pay attention to is that all fixing verbal semifinitives may be strong or super-weak; additionally for English, if a semifinitive does not begin with be / have, or is not be / (sometimes) have, it may be weak. If predicate needs no modal meaning, super-strong time specifier is not used. When forming subject we move from super-strong space specifier to weak one and take into account their pressure on the fixing verbal semifinitive. Of course we should not expect that the vacant fixing substantive semifinitive will obligatory become super-weak in the reciprocal sentence, since main infinitive units, in contrast to all other main substantive units (nouns, pronouns etc.), are not specially sought for. It could be however expected, that the vacant fixing substantive semifinitive will become weak, if the sought main substantive unit is a noun, striving to indefiniteness. Then this semifinitive will be fixed in the strong specifier. We see the aforementioned in the following constructions:

English:

Which girls do there see $\underline{\emptyset}$ Peter?*

Who does there see $\underline{\underline{\emptyset}}$ Peter?*

Which books are there lost $\underline{\underline{q}}$ ?* $^{*}$

What $\underline{\underline{\text { s }}} \underline{\text { there }} \underline{\underline{\text { lost }}} \underline{\underline{\emptyset}}$ ?

The construction Which girls do there see $\underline{\emptyset}$ Peter?* is extremely improbable because of the low capability of the semifinitive see to withstand the pressure of the strong specifier there and the high informativity of the interrogative element which girls. The construction Who $\underline{\underline{\text { does }}}$ 
there see $\underline{\underline{q}}$ Peter?* is rather improbable because of the low capability of the semifinitive see to withstand the pressure of the strong space specifier there (despite the low informativity of the interrogative element who). The construction Which books are there lost $\underline{\underline{a}} ?^{*}$ is also rather improbable because of the high informativity of the interrogative element which books (despite the high capability of the semifinitive be lost to withstand the pressure of the strong specifier there).

Dutch:

Welke meisjes zien $\underline{\text { er } \underline{\emptyset} \text { Peter?* }}$

Wie ziet $\underline{\text { er } \underline{\emptyset} \text { Peter? }}$

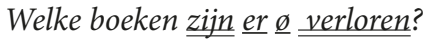

Wat is $\underline{\text { er } \underline{\emptyset} \text { verloren? }}$ ?

The construction Welke meisjes zien $\underline{\text { er }} \underline{\emptyset}$ Peter?* is rather improbable because of the high informativity of the interrogative element welke meisjes (despite the average capability of the semifinitive zien to withstand the pressure of the strong space specifier er - in Dutch much more verbal semifinitives are capable of it, than in English).

Swedish:

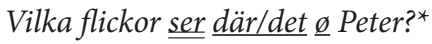

Vem ser $\underline{\text { där} / \text { det } \underline{\emptyset} \text { Peter?* }}$

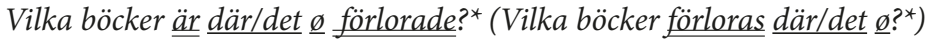

Vad är $\underline{\text { där/det }} \underline{\emptyset \text { förlorat? (Vad förloras }}$ där/det $\underline{\text { ? }}$ )

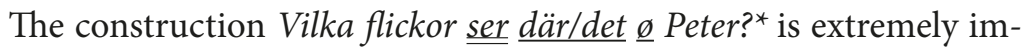
probable because of the low capability of the semifinitive se to withstand the pressure of the strong specifier där/det and the high informativity of the interrogative element vilka flickor. The construction Vem ser $\underline{\text { där/det }}$ $\underline{\emptyset}$ Peter ${ }^{*}$ is rather improbable because of the low capability of the semifinitive se to withstand the pressure of the strong space specifier där/ $\operatorname{det}$ (despite the low informativity of the interrogative element vem). The

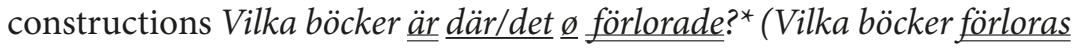
$\left.\underline{\text { där/det }} \underline{\text { q }}{ }^{*}\right)$ are also rather improbable because of the high informativity of the interrogative element vilka böcker (despite the high capability of the semifinitive vara förlorad/förlorat/förlorade (förloras) to withstand the pressure of the strong specifier där/det).

Still, as was said above, it is allowed for weak semifinitive to be fixed in weak specifier. Also one can expect that the vacant fixing substantive semifinitive will become strong, if the sought main substantive unit is a 
noun, striving to definiteness, proper noun or personal pronoun. This semifinitive will be fixed in the weak specifier. We see this in the following constructions:

English:

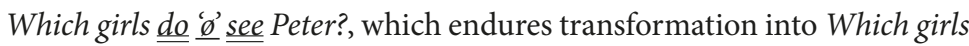
see 'Q’ Peter? Peter?

Who $\underline{\underline{\text { does }}} \underline{\underline{\emptyset}} \underline{\underline{\text { see }}}$ Peter?, which endures transformation into Who sees $\underline{\underline{\emptyset}}$

Which books are $\underline{\underline{0}} \underline{\underline{\text { lost}}}$ ?

What is ' $\underline{\text { ' }} \underline{\underline{\text { lost}}}$ ?

Dutch:

Welke meisjes zien ‘’ Peter?

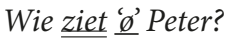

Welke boeken zijn '@’ verloren?

Wat $\underline{\underline{i s}} \underline{\text { 'D' }} \underline{\underline{\text { verloren? }}}$ ?

Swedish:

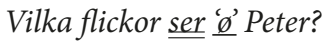

Vem ser 'ø' Peter?

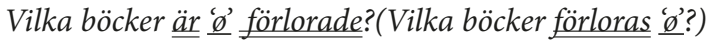

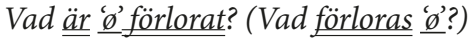

Thus, in independent clauses the absence or presence of strong specifier can be related to the possible opposition of fixing verbal semifinitive against the pressure of outer space for not weakening the lexical meaning. If the lexical meaning of main verbal unit may not be weakened, strong specifier is not used even when the concentration balance is frustrated; if a weakening is possible - the use of strong specifier is rather mainstreaming. The absence or presence of strong specifier can also be related to the informativity of the interrogative element. An interrogative element, narrowing the field of search for main substantive unit, is definitely more informative, and strong specifier, which gets no weak semifinitive to fix, is not used.

In dependent clause we deal with both narrative and interrogative sentences. When forming predicate we move from weak time specifier to super-strong one and do not take into account their pressure on the fixing substantive semifinitive. The only thing we should pay attention to is again that all fixing verbal semifinitives may be strong or su- 
per-weak; additionally, if a semifinitive does not begin with be / have, or is not be / (sometimes) have, it may be weak. If predicate needs no modal meaning, super-strong time specifier is not used. When forming subject we move from super-strong space specifier to weak one and take into account their pressure on the fixing verbal semifinitive.

English:

\begin{tabular}{|c|}
\hline 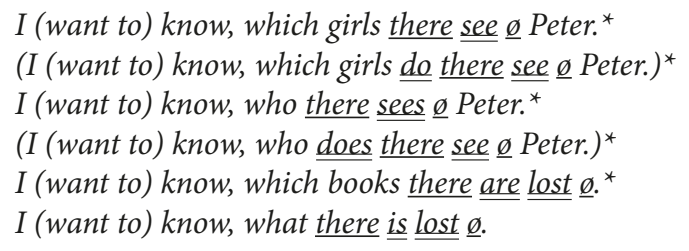 \\
\hline \\
\hline
\end{tabular}

The constructions I (want to) know, which girls there see $\underline{\emptyset}$ Peter. $^{*}$ (I (want to) know, which girls do there see $\underline{\emptyset}$ Peter.)* are extremely improbable because of the low capability of the semifinitive see to withstand the pressure of the strong specifier there and the high informativity of the conjunctive element which girls. The constructions I (want to) know, who there sees $\underline{\emptyset}$ Peter. ${ }^{*}(I \text { (want to) know, who does there see } \underline{\emptyset} \text { Peter. })^{*}$ are rather improbable because of the low capability of the semifinitive see to withstand the pressure of the strong space specifier there (despite the low informativity of the conjunctive element who). The construction I (want to) know, which books there are lost $\underline{\text { ø. }}{ }^{*}$ is also rather improbable because of the high informativity of the conjunctive element which books (despite the high capability of the semifinitive be lost to withstand the pressure of the strong specifier there).

Dutch:

Ik weet / wil weten, welke meisjes $\underline{\text { r }} \underline{\emptyset}$ Peter $\underline{\text { zien. }} .^{*}$

Ik weet / wil weten, wie er $\underline{\emptyset}$ Peter $\underline{\text { ziet. }}$.

Ik weet / wil weten, welke boeken $\underline{\text { er }} \underline{\underline{a}} \underline{\text { ijn }}$ verloren / verloren zijn.

Ik weet / wil weten, wat $\underline{\text { er }} \underline{\underline{\emptyset}}$ is verloren / verloren $\underline{\underline{i s}}$.

The construction Ik weet / wil weten, welke meisjes $\underline{\text { er }} \underline{\emptyset}$ Peter $\underline{\text { zien }} .{ }^{*}$ is rather improbable because of the high informativity of the conjunctive element welke meisjes (despite the average capability of the semifinitive zien to withstand the pressure of the strong space specifier er - as it has already been said, in Dutch much more verbal semifinitives are capable of it, than in English). 
Swedish:

Jag vet / vill veta, vilka flickor där/det ser $\underline{\text { g Peter. }}{ }^{*}$ Jag vet / vill veta vilka flickor $\underline{\text { som }} \underline{\underline{\text { ser }}} \underline{\underline{\emptyset}}$ Peter.

Jag vet / vill veta, vem där/det ser $\underline{\emptyset}$ Peter. ${ }^{*}$

Jag vet / vill veta vem som ser $\underline{\text { q Peter. }}$

Jag vet / vill veta, vilka böcker $\underline{\text { där/det }} \underline{\underline{a}} \underline{\underline{\emptyset}} \underline{\text { förlorade. }}{ }^{*}$

Jag vet / vill veta, vilka böcker som $\underline{\text { är }} \underline{\emptyset}$ förlorade. *

(Jag vet / vill veta, vilka böcker där/det förloras $\underline{\underline{\emptyset}}$ * $^{*}$

Jag vet / vill veta vilka böcker som förloras $\underline{\underline{q}}$. $\left.{ }^{*}\right)$

Jag vet / vill veta, vad där/det $\underline{\text { är }} \underline{\emptyset}$ förlorat.

Jag vet / vill veta vad som $\underline{\text { är }} \underline{\text { förlorat. }}$

(Jag vet / vill veta, vad där/det förloras $\underline{\emptyset}$.

Jag vet / vill veta vad som förloras ㅁ.

The constructions, which are not built on som, are extremely or rather improbable because of the reasons, already pointed out.

Still, as was said above, it is allowed for weak semifinitive to be fixed in weak specifier. Also one can expect that the vacant fixing substantive semifinitive will become strong, if the sought main substantive unit is a noun, striving to definiteness, proper noun or personal pronoun. This semifinitive will be fixed in the weak specifier. We see this in the following constructions:

English:

I (want to) know, which girls 'ø' see Peter.

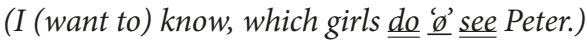

I (want to) know, who 'Q $\underline{\text { sees }}$ Peter.

(I (want to) know, who does 'Q' see Peter.)

I (want to) know, which books ' $\underline{\text { are }}$ lost.

I (want to know), what '向 $\underline{\text { is }}$ lost.

Theoretically and practically, there may also appear constructions like

I (want to) know, which girls ' $\underline{\text { ' see }}$ sere Peter. ${ }^{*}$

(I (want to) know, which girls do 'ø' $\underline{\text { see }}$ there Peter. $)^{*}$

I (want to) know, who 'ó $\underline{\text { sees }}$ there Peter. *

(I (want to) know, who does 'Q $\underline{\text { see }}$ there Peter. $)^{*}$

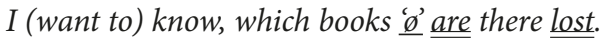

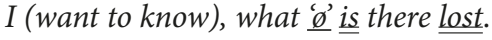


Such constructions, at first sight, cannot be properly explained, because the presence of there is here semantically and grammatically undue. Indeed, the subject in this construction is formed by vacant fixing strong substantive semifinitive in weak space specifier, and other units are not required. In Scandinavian languages, however, in the same construction one undertakes filling of the vacant strong substantive semifinitive with a unit of adverbial-substantive nature [Hultman, 2008; Jacobsen, Skyum-Nielsen, 2010]. In Swedish and Norwegian this unit is som, and in Danish - der. This makes us assume, that dependant clause in Scandinavian languages are provided with a complete main couple (subject and predicate), where there are no vacant semifinitives. It is not excluded, that the presence of there in the discussed English construction is welcome for achieving the same objective, but with a difference - in Scandinavian languages the vacant strong substantive semifinitive is filled with, and in English is accompanied by a adverbial-substantive unit. In Dutch for the vacant strong substantive semifinitive nothing is undertaken.

Dutch:

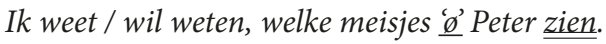

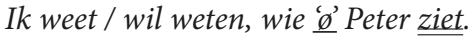

Ik weet / wil weten, welke boeken '追 zijn verloren / verloren zijn.

Ik weet / wil weten, wat ' $\underline{\text { ' }}$ is verloren / verloren $\underline{\underline{\text { is. }}}$.

Swedish:

Jag vet / vill veta vilka flickor $\underline{\text { som }} \underline{\underline{\text { ser }}} \underline{\emptyset}$ Peter.

Jag vet / vill veta vem som ser $\underline{\emptyset}$ Peter.

Jag vet / vill veta, vilka böcker $\underline{\text { som }} \underline{\underline{a} r} \underline{\emptyset}$ förlorade.

(Jag vet / vill veta vilka böcker som förloras $\underline{\text { q.) }}$

Jag vet / vill veta vad som $\underline{\text { är }} \underline{\emptyset}$ förlorat.

(Jag vet / vill veta vad som förloras $\underline{\text { ø.) }}$

Thus, in dependent clauses the absence or presence of strong specifier can be related to the possible opposition of fixing verbal semifinitive against the pressure of outer space for not weakening the lexical meaning. The absence or presence of strong specifier can also be related to the informativity of the conjunctive element. In Swedish and, very seldom, in English the vacant strong substantive semifinitive loses its being vacant with the help of an adverbial-substantive unit. This ensures the completeness of the main couple, which additionally becomes much 
more similar to main couples of independent clauses. Indeed, the most main couples of independent clauses, when space element precedes time element, are complete. Generally speaking, narrative and interrogative dependent clause is inbetween narrative independent clause and interrogative independent clause. Thus, from one side the fixation of strong substantive semifinitive in weak space specifier allows us not to take into account the pressure of the outer space; from another side the informativity of the conjunctive element may still define whether the vacant strong substantive semifinitive loses its being vacant or not. The low informativity can force the vacant strong substantive semifinitive to lose its being vacant and vice versa. This is very evident in Danish:

Jeg ved / vil vide, hvilke piger ( $\underline{\text { der })} \underline{\underline{s e r}} \underline{\emptyset}$ Peter.

Jeg ved / vil vide, hvem der ser $\underline{\underline{q}}$ Peter.

Jeg ved / vil vide, hvilke bøger ( $\underline{\text { der }}) \underline{\underline{e r}} \underline{\underline{q}} \underline{\underline{\text { tabte}}}$.

(Jeg ved / vil vide, hvilke bøger (der) tabes $\underline{\text {. }}$ )

Jeg ved / vil vide, hvad der $\underline{\underline{e r}} \underline{\underline{\text { tabt}}}$.

(Jeg ved / vil vide, hvad der tabes $\underline{\text { q.) }}$

Formal modeling consideration for dependent clause with vacant subject in some Germanic languages leads us to the conclusion, that the provision of vacant subject with a formal particle, having no lexical meaning - i.e. the fixation of vacant weak substantive semifinitive in strong space specifier is stipulated by two factors: the capability of the fixing verbal semifinitive to oppose against the pressure of the outer space and the informativity of the conjunctive element. Vacant strong substantive semifinitive, fixing in weak space specifier can lose its being vacant for making the main couple complete. The fixation of vacant or non-vacant strong substantive semifinitive in weak space specifier may sometimes be stipulated only by one factor - the informativity of the conjunctive element.

\section{REFERENCES}

Chomsky N. Language and mind. NY, Cambridge University Press Publ., 2006. $190 \mathrm{p}$.

Choumkov A. A. The partial and total modifications in their global difference. Aktualnye problemy sovremennoy lingvistiki: Materialy II nauchno-prakticheskoy konferentsii. St. Petersburg, ETU «LETI» Publ., 2013, pp. 65-67. (In Russian)

Finch G. Linguistic Terms and Concepts. NY, Palgrave Macmillan Publ., 2000. $263 \mathrm{p}$. 
Hultman T. G. Svenska Akademiens språklära [The Swedish Academy Grammar]. Stockholm, Norstedts Akademiska Förlag Publ., 2008. 342 p.

Jackendoff R. S. Foundations of Language. Brain. Meaning. Grammar. Evolution. NY, Oxford University Press Publ., 2003. 463 p.

Jacobsen H.G., Skyum-Nielsen P. Dansk sprog: en grundbog [Danish language: a ground book]. København, Schønberg Forlag Publ., 2010. 310 p.

Shumkov A. Modeling Natural Language on Physical Concepts. $6^{\text {th }}$ International Conference on Meaning and Knowledge Representation, Book of Abstracts. St. Petersburg, Expert-legal center Publ., 2017, pp. 68-69.

Szumkow A. A. Zur Präzisierung der Begriffs Semifinitiv im Sinne Zweiteiligheit. Metodichni ta psikhologo-pedagogichni problemi vikladannia inozemnikh mov na suchasnomu etapi: Materialy VII naukovo-metodichnoi konferentsii s mizhnarodnoiu uchastiiu. Kharkiv. KhNU imeni V.N. Karazina Publ., 2014, pp. 154-156.

Ulianitckaia L.A., Shumkov A.A. The physical base of communication on natural language. 2018 IEEE Communication Strategies in Digital Society Seminar (2018 ComSDS). St. Petersburg, ETU «LETI» Publ., 2018, pp. 72-75.

\section{А. А. Шумков}

Санкт-Петербургский государственный электротехнический университет

\section{К ВОПРОСУ О ФОРМАЛЬНОЙ МОДЕЛИ ЗАВИСИМЫХ ПРЕДЛОЖЕНИЙ С ПУСТЫМ ПОДЛЕЖАЩИМ В ГЕРМАНСКИХ ЯЗЫКАХ}

Для цитирования: Shumkov A. A. Formal modeling considerations for dependent clause with vacant subject in some Germanic languages // Скандинавская филология. 2018. Т. 16. Вып. 2. С. 292-307. https://doi.org/10.21638/11701/ spbu21.2018.207

Рассмотрены зависимые предложения с пустым подлежащим в сопоставлении с независимыми предложениями с пустым подлежащим, относящимися к случаю вопросительных конструкций, в которых подлежащее неизвестно и разыскивается с помощью обязательного вопросного элемента. Привлекаются преимущественно материалы английского, нидерландского и шведского языков. В целях выявления синтаксической природы формальной частицы подлежащего применена формальная модель на основе идеи двухчастности. Субстантивные/ глагольные члены предложения, главные или второстепенные, представляются состоящими из двух частей - пространственного/временного уточнителя, или прауточнителя, и субстантивного/глагольного семифинитива. Формальная частица подлежащего сопоставляется с сильным или сверхсильным пространственным уточнителем. Постулируется, что в независимом и зависимом вопросительном, а также в зависимом повествовательном предложениях процесс фиксации главного субстантивного семифинитива начинается со сверхсильного уточнителя. Высказано предположение, что в независимых/зависимых предложениях использование формальной частицы обусловлено возможным противостоянием фиксирующегося глагольного семифинитива давлению внешнего 
пространства, а также информативностью вопросного/союзного элемента. Для зависимых предложений также установлено, что формальная частица в датском и иногда английском языках может заполнять (или сопровождать) пустой сильный субстантивный семифинитив, отчего он перестает быть пустым. В этих же целях шведский и норвежский языки используют вместо формальной частицы наречно-субстантивную единицу. Заполнение пустого сильного субстантивного семифинитива делает главные члены предложения полноценными, и зависимые предложения становятся более похожими на независимые. Тем самым подтверждается тезис идеи двухчастности о том, что синтаксически повествовательное/вопросительное зависимое предложение располагается между повествовательным независимым и вопросительным независимым. Тем не менее использование пустого или непустого сильного субстантивного семифинитива может быть обусловлено, как в датском языке, информативностью союзного элемента. В случае высокой информативности союзного элемента сильный субстантивный семифинитив может оставаться пустым.

Ключевые слова: лингвистическое моделирование, синтаксис германских языков, зависимые предложения, нулевое подлежащее, идея двухчастности, семифинитив.

\section{Andrei Shumkov}

Doctor in Philology, Associate Professor,

Saint Petersburg state electrotechnical university,

5, ul. Professora Popova, St. Petersburg, Russia, 197376

E-mail: noizen@mail.ru

Received: July 16, 2018

Accepted: August 30, 2018 